\title{
SOME OBSERVATIONS ON THE EFFECT OF INJECTED CYTOCHROME C IN ANIMALS ${ }^{1}$
}

\author{
By SAMUEL PROGER, DEMETRE DEKANEAS, AND GERHARD SCHMIDT \\ (From the Joseph H. Pratt Diagnostic Hospital and Tufts Medical School, Boston)
}

(Received for publication May 31, 1945)

In previous communications it was suggested that respiratory catalysts might be used to help maintain normal functions of tissues under conditions of anoxia by their enhancing effect on tissue respiration $(1,2,3,4)$. Even under conditions of anoxia, there is in the returning venous blood a considerable amount of oxygen which might theoretically be made available to the anoxic tissue through the effect of an additional supply of a respiratory catalyst. That one could apparently produce an increased local tissue uptake of oxygen under conditions of anoxia in vivo through the use of the hydrogen donator, succinic acid, has previously been demonstrated $(1,2)$. Cytochrome $\mathrm{C}$, in combination with cytochrome oxidase, is one of the most important respiratory enzyme systems and the following report deals with some effects of cytochrome $\mathrm{C}$. An additional reason for the selection of cytochrome $\mathrm{C}$ for our studies is the fact that it is present in normal tissues in amounts far below what is required for the full activation of the cytochrome-cytochrome oxidase system. That is to say, there is relatively more cytochrome oxidase present in the organs than is necessary for activation by the cytochrome $C$ present, as noted in Table I. These figures are

TABLE I

Gammas cytochrome $C$ per gram of fresh tissue

$\begin{array}{ccc}\text { Organ (rat) } & \begin{array}{c}\text { Required for half } \\ \text { of maximal activa- } \\ \text { tion of oxidase }\end{array} & \begin{array}{c}\text { Found } \\ \text { by } \\ \text { analysis }\end{array} \\ \text { Heart } & 1700 & 371 \\ \text { Kidney } & 860 & 247 \\ \text { Liver } & 675 & 90 \\ \text { Brain } & 720 & 50\end{array}$

based on calculations from data reported by other workers (5). Hence; if additional cytochrome C could be supplied to the organs, it might be expected to be effective.

1 This work was done with the aid of grants from Brewer \& Company, Inc., and the Charlton Fund.

\section{The accumulation of injected cytochrome $C$ in organs}

It is obvious that injected cytochrome $\mathrm{C}$ can be effective only if it actually penetrates to the organs. Since cytochrome $\mathrm{C}$ is a protein and thus a large molecule, there was uncertainty as to whether it would pass through the capillaries sufficiently to accumulate in the organs in effective amounts.

TABLE II

Cytochrome $C$ content of organs and blood of rats before and after injection

1. Cytochrome $\mathbf{C}$ content of organs (gammas per gram) of rats

\begin{tabular}{c|l|c|c|c}
\hline No. of animals used & Organ & Minimum & Maximum & Average \\
\cline { 2 - 4 } & Heart & 185 & 270 & 220 \\
15 & Kidney & 126 & 245 & 188 \\
15 & Liver & 60 & 165 & 120 \\
2 & Spleen & 105 & 110 & 108 \\
\hline
\end{tabular}

2. Cytochrome $\mathrm{C}$ content of organs (gammas per gram) and blood (gammas per $100 \mathrm{ml}$.) of rats 30 minutes after intravenous injection of Cytochrome $\mathbf{C}$

\begin{tabular}{|c|c|c|c|c|c|c|}
\hline $\begin{array}{l}\text { Amt. of } \\
\text { Cyt. c } \\
\text { injected }\end{array}$ & $1 \mathrm{mgm}$. & $2 \mathrm{mgm}$. & $5 \mathrm{mgm}$. & $10 \mathrm{mgm}$. & $20 \mathrm{mgm}$. & $50 \mathrm{mgm}$. \\
\hline $\begin{array}{l}\text { Blood } \\
\text { Heart } \\
\text { Kidney } \\
\text { Liver } \\
\text { Spleen }\end{array}$ & $\begin{array}{l}393 \\
360 \\
163 \\
140\end{array}$ & $\begin{array}{r}35 \\
305 \\
362 \\
187 \\
290\end{array}$ & $\begin{array}{l}102 \\
440 \\
291 \\
225 \\
147\end{array}$ & $\begin{array}{l}185 \\
230 \\
350 \\
250 \\
570\end{array}$ & 680 & $\begin{array}{l}257 \\
215 \\
765 \\
178\end{array}$ \\
\hline
\end{tabular}

Furthermore, if it did accumulate, it was necessary to obtain information as to how long it remained unchanged in the organs. We found that it was in fact possible to increase the organ content of cytochrome $\mathrm{C}$ after injection and that this injected substance was relatively stable. ${ }^{2}$

Table II shows the amounts of cytochrome $\mathrm{C}$ in organs and blood of control animals (rats) and in

\footnotetext{
2 The method of determining the organ content of cytochrome $\mathrm{C}$ was that of Potter and Dubois (5). The method for preparing cytochrome $\mathrm{C}$ was that of Keilin and Hartree (6).
} 
animals following the intravenous injection of varying amounts of cytochrome $\mathrm{C}$. It will be noted that there is a distinct increase in the organ content of cytochrome $\mathrm{C}$ following the injection of as little as $1 \mathrm{mgm}$. of the substance. It is of interest to note further that increasing amounts of injected cytochrome $\mathrm{C}$ beyond a certain amount (in these experiments, 5 to $10 \mathrm{mgm}$. intravenously) seem to produce a paradoxical effect on the content of cytochrome in the heart and liver so that with doses of more than 5 to $10 \mathrm{mgm}$. of cytochrome $\mathrm{C}$ intravenously, there is not a further increase in these organs of cytochrome $\mathrm{C}$, but rather a decrease toward the normal values. On the other hand, in the kidneys and spleen and in the blood as well the content of cytochrome $C$ continues to rise with increasing doses of the injected substance.

TABLE III

Cytochrome $C$ content in organs of rats after injection intravenously and intramuscularly

1. Cytochrome $\mathbf{C}$ content in organs of rats (gammas per gram) after intravenous injection of $2 \mathrm{mgm}$. of cytochrome C

\begin{tabular}{l|c|c|c|c}
\hline Time after injection & \multicolumn{2}{|c|}{ minutes } & \multicolumn{2}{|c}{ hours } \\
& 30 & 60 & 2 & \multicolumn{1}{c}{15} \\
\hline Heart & 378 & 303 & 303 & 165 \\
Kidney & 380 & 335 & 150 & 120 \\
Liver & 203 & 142 & 76 & 58 \\
\hline
\end{tabular}

2. Cytochrome $\mathbf{C}$ content in organs of rats (gammas per gram) after intramuscular injection of 2 mgm. of cytochrome C

\begin{tabular}{l|c|c|c|c}
\hline \multirow{2}{*}{ Time after injection } & \multicolumn{2}{|c|}{ minutes } & \multicolumn{2}{|c}{ hours } \\
& 30 & 60 & 2 & 15 \\
\hline Heart & 261 & 234 & 360 & 220 \\
Kidney & 203 & 222 & 240 & 254 \\
Liver & 113 & 108 & 124 & 175 \\
\hline
\end{tabular}

Table III shows the relative increase in the cytochrome $\mathrm{C}$ content of organs following intramuscular and intravenous injections. There is seen to be a slower and less marked rise following intramuscular injection as compared with the intravenous injection.

Changes similar to these in rats were observed after injections of cytochrome $\mathrm{C}$ in rabbits.

Physiological effects of injected cytochrome $C$.

In vitro experiments. Having demonstrated that cytochrome $\mathrm{C}$ is relatively stable in the intact animal and that the organ content of the substance could be increased following parenteral injection, it remained to determine whether such an increase of cytochrome $\mathrm{C}$ as we could produce in the organs was of a sufficient magnitude to increase the oxygen uptake of the tissue. We approached this problem by studying the influence of added cytochrome $\mathrm{C}$ on the oxygen uptake of isolated rat organs. That the increase of cytochrome $\mathrm{C}$ of this general order of magnitude could produce a significant increase in the oxygen uptake of homogenized tissue suspensions is demonstrated in Table IV. The concentration of cytochrome $\mathrm{C}$ in

TABLE IV

$\mathrm{O}_{2}$ consumption during 10 minutes incubation at $37^{\circ} \mathrm{C}$. (mm. $^{8} \mathrm{O}_{2}$ per $100 \mathrm{mgm}$. fresh tissue) ${ }^{3}$

Organ (rat)
Liver
Kidney
Kidney
Heart

No cytochrome C
added beyond usual
content
41
50
54
24

300 gammas cyto-
chrome C added
per ml. medium
60
79
97
50

the Ringer's solution serving as medium for the homogenized tissue suspensions was made to correspond with that found in the organs of the injected animals.

It will be seen that there is under such circumstances an increase of oxygen consumption of about 50 to 100 per cent. It would appear, therefore, on theoretical grounds that we were able to increase significantly the conditions for oxygen uptake in the organs studied by the increase in the cytochrome $\mathrm{C}$ content of the organs resulting from the injections.

In vivo experiments. The observations on the enhancing effect of added cytochrome $\mathrm{C}$ on the oxygen uptake of isolated tissues raised the question as to whether similar effects might be demonstrated in intact animals. The total oxygen consumption of normal dogs was found to be unchanged after the injection of as much as $50 \mathrm{mgm}$. of cytochrome $\mathrm{C}$ intravenously. We then made observations on the arteriovenous oxygen differences to determine whether there was evidence of increased tissue uptake of oxygen as indicated by a decrease in the venous content of oxygen. The venous blood was obtained under nembutal anes-

\footnotetext{
3 Total volume $3.5 \mathrm{ml}$., side arm $0.5 \mathrm{ml}$. 1 per cent hydroquinone solution. Buffer: $1 \mathrm{ml}$. $\mathrm{N} / 10$ sodium phosphate mixture ( $\mathrm{pH}$ 7.2).
} 
thesia by catheterization of the right auricle. Table $\mathrm{V}$ shows the result of experiments in the same animal with and without cytochrome $C$. There is seen to be a decrease in the venous content of oxygen following the injection of cytochrome $\mathrm{C}$, whereas in the control there was no such decrease. Similar, though not so striking results, were obtained in other dogs. This decrease in venous content of oxygen may be taken as an indication of the increased tissue uptake of the oxygen. Since we could not determine arteriovenous oxygen differences in the dog without anesthesia and since the anesthesia in itself may be associated with some anoxia, we were unable to make observations on the effects of injected cytochrome $\mathrm{C}$ on the arteriovenous oxygen differences in dogs without some possible anoxia as a result of the anesthesia. However, we were able to obtain such observations in human beings through the cooperation of another investigator." The results of his observations indicate that from 10 to 30 minutes following the intravenous injection of 100 to $120 \mathrm{mgm}$. of cytochrome $\mathrm{C}$, there is no effect on the arteriovenous oxygen difference in human beings under conditions of normal oxygen tension.

The blood level of cytochrome $C$ after intravenous injections. The next observations dealt with the effect of injected cytochrome $C$ on blood content. Normally, there is no detectable cytochrome $\mathrm{C}$ in the circulating blood. Table VI shows the blood content of cytochrome $\mathrm{C}$ follow-

Assistance in these experiments was given by Dr. Eugene Stead, of Emory University.

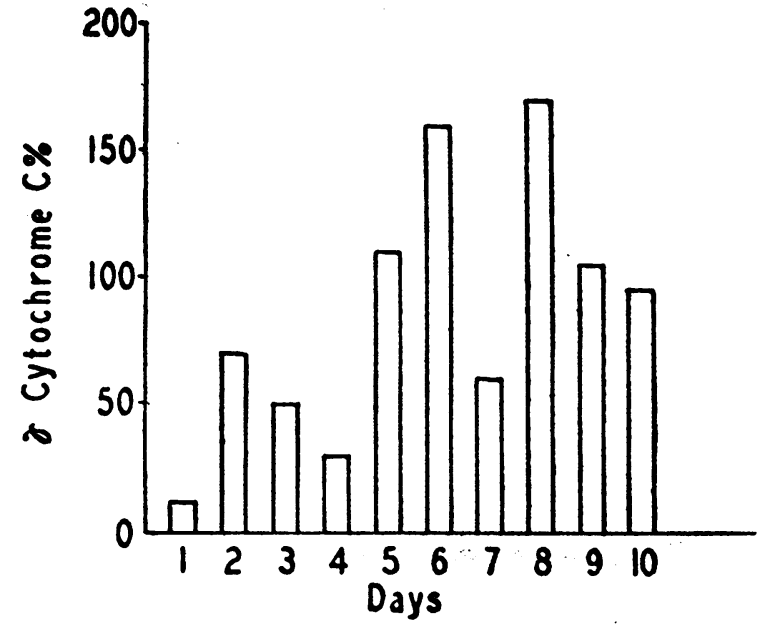

Fig. 1. Dog's Blood Level of Cytochrome C after DaILy INJECtion of 40 MGM. InTRAVENOUSLY

ing the intramuscular and intravenous injection of the substance in rats. Just as in the organs, the difference appears to be chiefly that the rise following intramuscular injection is slower than that following intravenous injection. The cytochrome $\mathrm{C}$ remains in the blood following injection for a sufficiently long time so that a blood level could be established and maintained with an injection of cytochrome $\mathrm{C}$ every 24 hours as noted in Figure 1. After a few days, there is in the dog a blood level of about 100 to 150 gammas per cent following the daily injection of $40 \mathrm{mgm}$. of cytochrome C intravenously. The values were obtained in each instance 24 hours after the previous injection.

There was a striking difference in the blood content of cytochrome $\mathrm{C}$ following injection depending upon whether or not the animals were

TABLE $v$

Dog No. 3

Effect of cytochrome $C$ on arteriovenous oxygen difference

\begin{tabular}{|c|c|c|c|c|c|c|c|c|c|c|c|c|c|}
\hline \multirow{3}{*}{ Date } & \multirow{3}{*}{$\begin{array}{c}\text { Arterial } \\
\mathrm{O}_{2} \text { yol. } \\
\%\end{array}$} & \multirow{3}{*}{$\mid \begin{array}{c}\text { Venous } \\
\text { Oz vol. } \\
\%\end{array}$} & \multirow{3}{*}{$\begin{array}{l}\text { A-V } \\
\text { Diff. }\end{array}$} & \multicolumn{10}{|c|}{$10 \%$ Anoxia } \\
\hline & & & & \multicolumn{4}{|c|}{20 minutes } & \multicolumn{3}{|c|}{40 minutes } & \multicolumn{3}{|c|}{60 minutes } \\
\hline & & & & $\begin{array}{c}\text { Arterial } \\
\mathrm{O}_{2} \text { vol. } \\
\%\end{array}$ & $\begin{array}{c}\text { Venous } \\
\text { O2 vol. } \\
\%\end{array}$ & $\begin{array}{l}\text { A-V } \\
\text { Diff. }\end{array}$ & Procedure & $\begin{array}{c}\text { Arterial } \\
\mathrm{O}_{2} \text { vol. } \\
\%\end{array}$ & $\begin{array}{c}\text { Venous } \\
\text { Oavol. } \\
\%\end{array}$ & $\begin{array}{l}\text { A-V } \\
\text { Diff. }\end{array}$ & $\begin{array}{c}\text { Arterial } \\
\mathrm{O}_{2} \text { vol. } \\
\%\end{array}$ & $\mid \begin{array}{c}\text { Venous } \\
\text { Os vol. } \\
\%\end{array}$ & A-V \\
\hline $2-28-44$ & 14.75 & 9.78 & 4.97 & 10.34 & 5.40 & 4.94 & $\begin{array}{c}\mathrm{NaCl} \\
\text { N. Sol. } \\
5 \text { ml. I.V. }\end{array}$ & 10.30 & 6.07 & 4.23 & 10.27 & 5.90 & 4.37 \\
\hline $3-21-44$ & 12.23 & 9.78 & 2.45 & 6.24 & 3.11 & 3.13 & $\begin{array}{l}\text { CYT.C. } \\
25 \text { mgm. } \\
\text { I.V. }\end{array}$ & 6.21 & 1.67 & 4.54 & 6.45 & 1.41 & 5.04 \\
\hline
\end{tabular}


TABLE V

Cytochrome $C$ content in blood of rats injected with 2 mgm. cytochrome $C$, intravenously and intramuscularly

\begin{tabular}{l|c|c|c|c|c|c|c}
\hline \hline & Time after injection & $10^{\prime}$ & $20^{\prime}$ & $30^{\prime}$ & $1 \mathrm{hr}$. & $2 \mathrm{hrs.}$ & $24 \mathrm{hrs.}$ \\
\hline Intravenous & $\begin{array}{c}\text { Cytochrome C } \\
\text { (gammas per 100 ml.) }\end{array}$ & 83 & 83 & 71 & 70 & 68 & 12 \\
\hline Intramuscular & $\begin{array}{c}\text { Cytochrome C } \\
\text { (gammas per 100 ml.) }\end{array}$ & 34 & 32 & 36 & 32 & 88 & 3 \\
\hline
\end{tabular}

under anesthesia. Without anesthesia, the blood levels were considerably higher as shown in Figure 2.

The depressing effects of anoxia and anesthesia on the blood content of cytochrome $\mathrm{C}$ are additive as shown in Figure 3 where, when anoxia is added to anesthesia, there is a considerable decrease in the blood content and an increase again when the effect of anoxia is released. In this experiment, the anesthesia effect was present throughout the first 4 hours.

This is an interesting phenomenon and raises the question as to what happens to the cytochrome

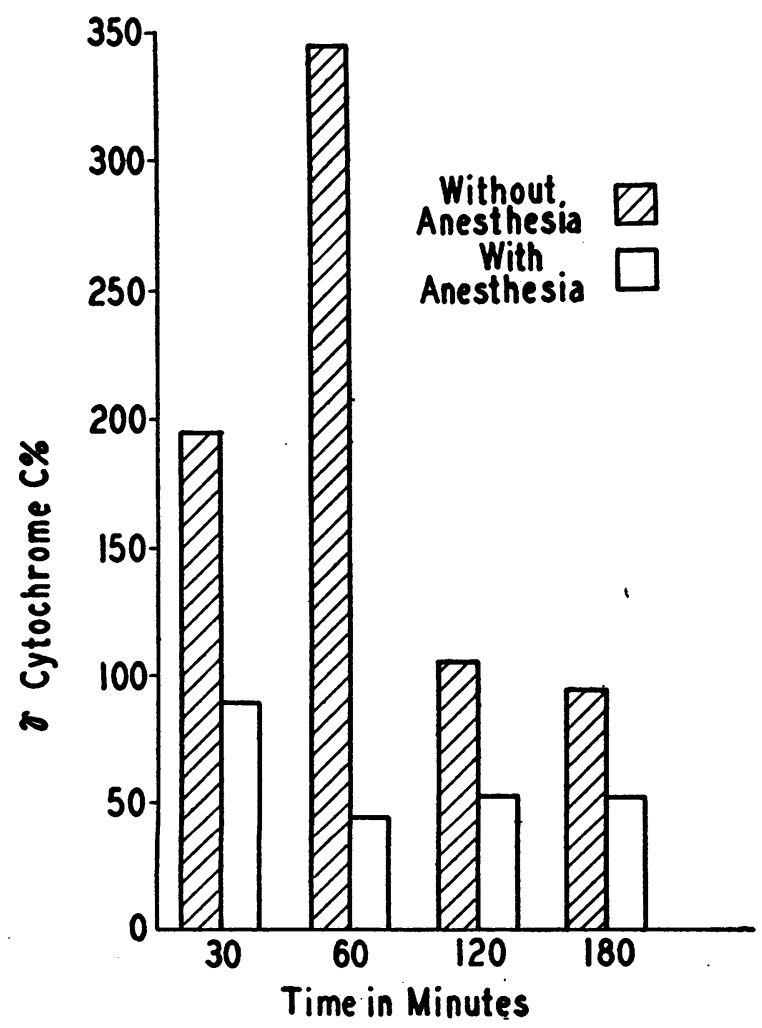

Fig. 2. Blood Level of Cytochrome C after I. V. INJECTION OF 30 MGM. WITH AND WITHOUT NEMBUTAL ANESTHESIA

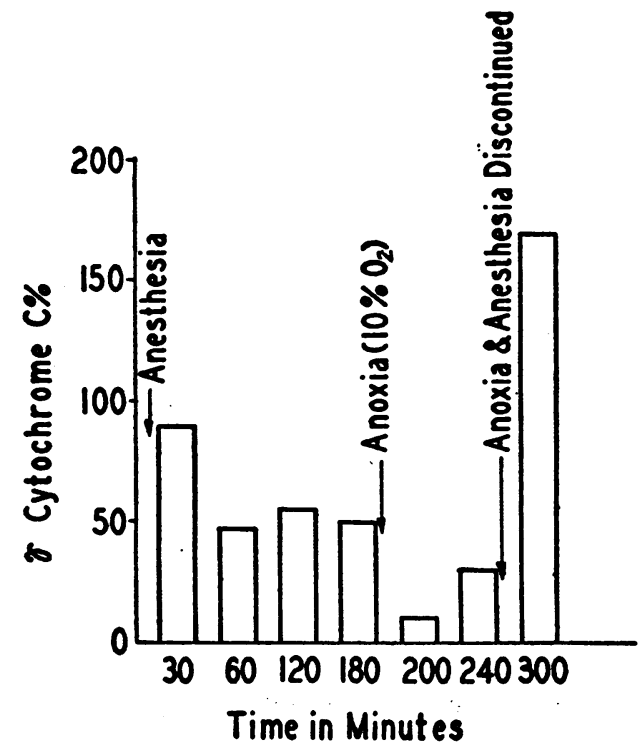

Fig. 3. The Effect of Anoxia on the Blood Level of Cytochrome C after I. V. InJection of 30 MGM. IN ANesthetized DoG

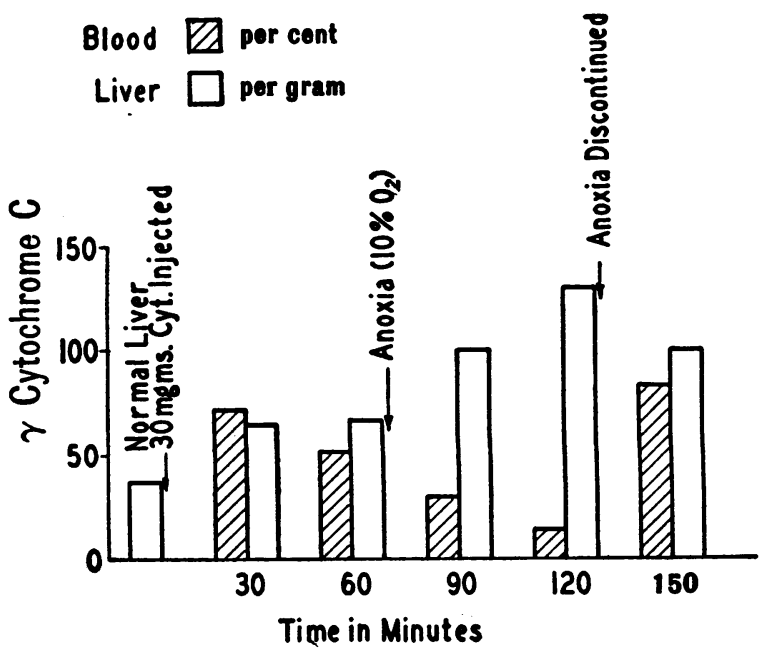

Fig. 4. Simultaneous Determinations of Cytochrome C Content in Blood and Liver of Dogs after I. V. IN.Jection of 30 MGM. AND the EFFECT OF ANoxia 
$\mathrm{C}$ under conditions of anesthesia and anoxia. The answer appears to be that there is a reciprocal relationship between the cytochrome $\mathrm{C}$ content of the blood and the liver, so that as the level in the blood decreases as a result of anoxia, the content in the liver simultaneously increases. This reciprocal relationship is demonstrated in Figure 4. Our observations on this phenomenon were limited to the liver because this is the only organ easily susceptible to repeated biopsies for tissue analyses without serious impairment to the total functioning of the body. A similar situation may well be obtained in the other organs. This phenomenon suggests that the supply of cytochrome $C$ circulating in the blood stream acts as a reservoir to be called upon as the need arises and to be replenished when the need no longer exists.

The ultimate fate of the injected cytochrome $\mathrm{C}$ is obscure. There is reason to suspect that it is at least largely broken down before excretion inasmuch as we were never able to recover it in the urine. Nor were we able to recover porphyrin, one of its possible breakdown products.

\section{SUM MARY}

1. The cytochrome $\mathrm{C}$ content of organs (heart, brain, liver, and kidney) is far below that required for the maximal activity of the cytochrome oxidase present. This apparent suboptimal condition for the action of the cytochrome-cytochrome oxidase system in normal tissues led us to attempt first to increase the cytochrome $\mathrm{C}$ content of the organs and then to study the effects resulting from supplying such additional cytochrome $\mathrm{C}$.

2. We find that cytochrome $\mathrm{C}$ prepared from beef hearts is stable, non-toxic in large doses, recoverable from the blood, and in increased amounts from the organs after intravenous and intramuscular injections, and apparently broken down before excretion because it is not recoverable in the urine.

3. Following the intravenous injection of cytochrome $\mathrm{C}$, there is a considerable increase in the content of this substance in the heart, liver, and kidney of the rat and rabbit. There is a similar, though delayed, increase following intramuscular injection.
4. It has been demonstrated by in vitro experiments that an increase of cytochrome $\mathrm{C}$, similar to that produced in living organs by injection is sufficient to produce a significant increase in tissue uptake of oxygen.

5. In the dog, under conditions of anoxia, injected cytochrome $\mathrm{C}$ increases the arteriovenous oxygen difference, presumably by increasing the withdrawal of oxygen from the arterial blood. Under conditions of normal oxygen tension, injected cytochrome $\mathrm{C}$ does not influence the arteriovenous oxygen difference in man.

6. By daily intravenous injections, a satisfactory blood level can be maintained.

7. Under conditions of anoxia, the liver content of cytochrome $\mathrm{C}$ increases after injection, whereas the blood level decreases. With release from anoxia, there is a decrease in liver content and an increase in blood level. This suggests that the supply of cytochrome $\mathrm{C}$ circulating in the blood stream acts as a reservoir to be called upon as the need arises and to be replenished when the need no longer exists.

This work was done with the technical assistance of Mrs. Bella Wadler.

\section{BIBLIOGRAPHY}

1. Proger, S., Aisner, M., and Squires, R. B., The prevention of electrocardiographic evidences of myocardial anoxemia by chemical means. J. Clin. Invest., 1942, 21, 630.

2. Proger, S., The use of respiratory catalysts, particularly succinic acid, in tissue anoxia. Bull. New England M. Center, 1943, 5, 80.

3. Proger, S., Dekaneas, D., and Schmidt, G., The increase of cytochrome $\mathrm{C}$ content of organs following its parenteral injection. J. Clin. Invest., 1944, 23, 949.

4. Proger, S., Some effects of injected cytochrome $C$ in animals and man. Bull. New England M. Center, 1945, 7, 1.

5. Potter, V. R., and DuBois, K. P., The quantitative determination of cytochrome C. J. Biol. Chem., 1942, 142, 417.

6. Keilin, D., and Hartree, E. F., Preparation of pure cytochrome $\mathrm{C}$ from heart muscle and some of its properties. Proc. Roy. Soc., London, Series B., 1937, 122, 298. 